\title{
COVID-19 Pandemic and Its Impact on Indian and Global Economies
}

\author{
K.Kareemulla ${ }^{1}$, S.Ravichandran ${ }^{1 *}$ and Suvangi Rath ${ }^{2}$ \\ ${ }^{1}$ ICAR-National Academy of Agricultural Research Management, Hyderabad, India \\ ${ }^{2}$ Odisha University of Agriculture and Technology, Bhubaneswar, Odisha, India \\ *Corresponding author: ravichandran@naarm.org.in (ORCID ID: 0000-0002-7581-3781)
}

Received: $17-04-2020$

Revised: $12-07-2020$

Accepted: 24-08-2020

\begin{abstract}
COVID-19, a pandemic disease caused by the coronavirus originated from China has been ravaging the entire global nations due to which the entire global economy is in the doldrums. The disease has been there in the entire globe since November 2019 and is expected to damage human beings and the world economies for a long time. In this article, we discuss the damage caused by the deadly virus to the Indian economy and the world economy as a whole. A word of caution is that until the vaccine is invented, the economies world will suffer to the maximum extent since most of the major economies of the globe are locked down due to the pandemic.

Highlights

( The article highlights the implication of the COVID-19 pandemic outbreak on the Economy of India and the world at large.
\end{abstract}

Keywords: COVID-19, coronavirus, global economy, India

A virus is an infectious agent of small size and simple composition that can multiply only in living cells of animals, plants, or bacteria as per Encyclopedia Britannica (https://www.britannica. com/science/virus). Virologists define virus as a nonliving thing (https://www.virology.ws/2004/06/09/ are-viruses-living/). As per the World Health Organization (WHO), COVID-19 is the infectious disease caused by the most recently discovered coronavirus. This new virus and disease were unknown before the outbreak began in Wuhan, China, in December 2019. COVID-19 is now a pandemic affecting many countries globally (WHO, 2020). In the last century, a few pandemics have caused havoc and significant among them was the Spanish Flu that resulted in the death of about 50 million people (Bahadur et al. 2020). COVID-19 pandemic is causing panic and havoc across the globe ever since it was first noticed in China during December 2019. As on the morning of August 24, 2020, a total of 212 Countries and Territories around the world have reported a total of 5567217 confirmed cases of the coronavirus COVID-19 that originated from Wuhan, China, and a death toll of 800906 (Worldometers, 2020, as on 24 August 2020). Thus, the death rate was $3.47 \%$ globally. In India, 3044940 persons are infected and the deaths due to this disease are 56706 which results in the death rate of $1.86 \%$ which is just half of the global death rate. But since India has been under continuous lockdown, the infection and death rates are controlled. It is believed that the country will face severe infection problems in June, July and August 2020 since countries like India cannot afford to be under lockdown for a long time.

Looking at the magnitude of the COVID-19 pandemic which has engulfed almost all the

How to cite this article: Kareemulla, K., Ravichandran, S. and Rath, S. (2020). COVID-19 Pandemic and Its Impact on Indian and Global Economies. Economic Affairs, 65(3): 451-458.

Source of Support: None; Conflict of Interest: None 
countries of the world (212 countries affected so far), large and small, developed and developing all are affected. Every country has adopted some precautionary measure or the other to keep a check on the spread of the disease and minimize the damage both monetary and human life. The results of management by the countries affected are varied. Because of this, an analysis of the impact of the pandemic given the countries fundamentals - health, economic and other indicators and their relationship with the cause and effect are analyzed in this paper. The paper aims to answer the following questions:

- Level of incidence and mortality - does it indicate the building of immunity or otherwise

- Relationship between the extent of health infrastructure and health status of the population across countries and incidence

- The recovery rate of COVID -19 infected people vs. the health status of people

- Coverage of tests across countries - does this indicate any trend of pandemic density?

- As social/physical/ isolation distance is being talked of as a precaution, whether the level of urbanization has any tendency towards higher incidence in such countries

- Per capita income, the growth rate of economies, foreign exchange reserves and unorganized labour status - How these things influence the stability or otherwise of countries to get revival post COVID- 19 devastation.

\section{MATERIALS AND METHODS}

The study includes secondary data to analyze the impacts of the pandemic on the economies of India and globe. The data was collected using secondary sources viz. WHO, Worldometers 2020. The analysis was carried out by calculating various indices such as mortality percentage, recovery rate and economic complexity indices. Scale measurement like ratio was carried out during the analysis. Correlation coefficients were calculated to find the extent of relationship between the rate of recovery and the number of hospital beds and number of physicians. Growth rates of a few parameters were also worked out using standard formulae.

\section{RESULTS AND DISCUSSION}

\section{Incidence of COVID-19 across Countries}

The coronavirus disease -19 , so named which first appeared in China's province of Wuhan during December 2019 and has spread gradually in the next five months to the entire globe. Since the symptoms of the disease are similar to flu, people were not serious initially but as these symptoms led to death among people with chronic ailments such as diabetes, hypertension, cardiac disease etc. and also in normal people, the people in general and the respective governments, in particular,took the pandemic disease seriously. Measures initiated varied across the countries which included isolation of patients with COVID 19 symptoms, specialized hospitals, quarantine centres and imposing lockdown to restrict the movement of the general public from getting exposed to the virus from infected people. Despite these measures, the disease is not subsiding and mixed responses to the management measures are emerging from across the world. This paper is attempted to assess and analyze the underlying factors.

The COVID-19 Incidence of across the countries as available from Worldometer (accessed on 24 August 2020, https://covid19. who.int/? gclid=EAIaIQobChMIx Lqux li46wIVhyQrCh1YJQSBEAAYASAAEgKqa_D_BwE) was taken and sifted as two country groups, with the least incidence limit as around 30000 in a country. Accordingly, the first group segregated as heavily infected countries and the other one as least infected countries (Fig. 1-3). Ten countries in each group were considered for relating the total cases and proportion of infected population. In the heavily infected countries USA with as high as 5.6 million population topped the list followed by Brazil and India. These ten countries together accounted for almost two-thirds of the world's total cases. In terms of the proportion of population affected in these countries, Peru (17.5/ 1000 population) and Brazil (16.6/ 1000 population) lead the group while India had the least share of affected people (2.2/ 1000 people).

Among the bottom of the list of the countries, where infestation is over and above 30000 cases, Nepal was the least affected with just 31000 total cases preceded by Kenya (32.1 thousand cases) and so 
on (Fig. 2). The disease incidence i.e. the number of cases per thousand people was the highest in the Republic of Moldova ( 8.2 ) followed by Costa Rica (6.3) and the least incidence was in the case of Ethiopia (0.3/1000 population).

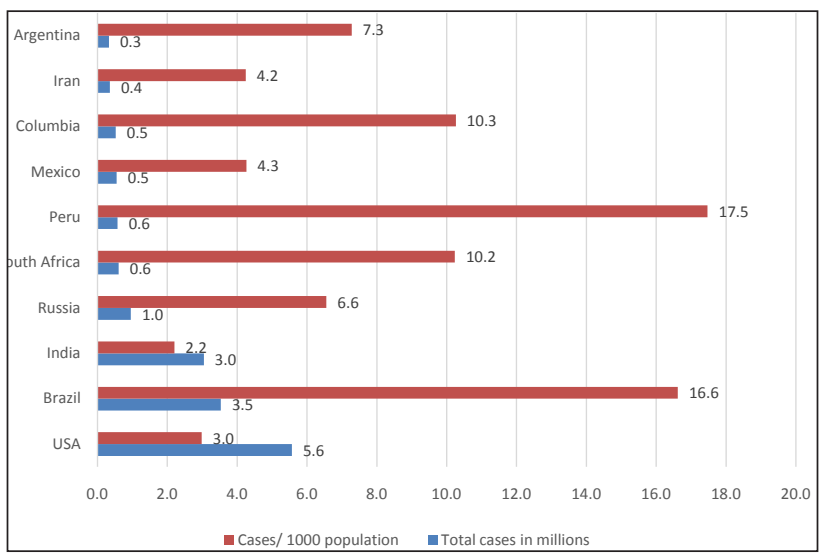

Fig. 1: COVID-19 Incidence in Heavily Infected Countries

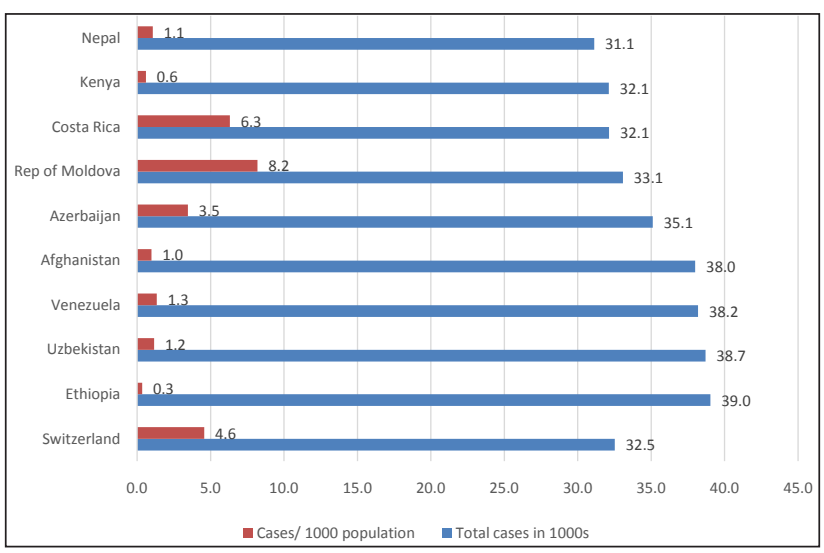

Fig. 2: COVID-19 Incidence in Least Infected Countries

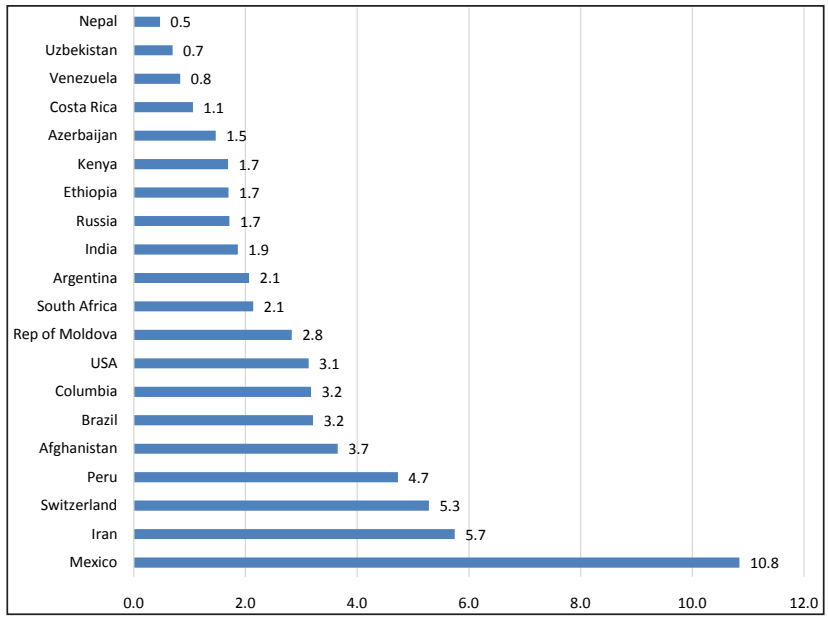

Fig. 3: Mortality Rate Due to COVID-19 (no of deaths/ 100 infected populations)

Data source: https://covid19.who.int/?gclid $=$ EAIaIQobChMI $x$ LquxIi46wIVhyQrCh1Y JQSBEAAYA SAAEgKqa_D_BwE, accessed on 24 Aug 2020)

The rate of mortality due to COVID-19 infection was the highest at $10.8 \%$ in Mexico followed by Iran $(5.7 \%)$. In the highly infected country like USA it was $3.1 \%$ and in India it was $1.9 \%$ (Fig. 3). It was less than one in the least infected countries like Venezuela and Nepal.

\section{Health Infrastructure of Affected Countries}

After an initial understanding of the incidence and mortality levels of this virus attack on humans, the status of health infrastructure and the general health of the population in those countries was compared. The hypothesis is that better the health of a country's

Table 1: Medical infrastructure, Indices Vis a Vis Infected Cases and Mortality

\begin{tabular}{|c|c|c|c|c|c|c|}
\hline Country & $\begin{array}{l}\text { Physicians/ } \\
1000 \text { people }\end{array}$ & $\begin{array}{l}\text { Hospital beds/ } \\
1000 \text { people }\end{array}$ & $\begin{array}{l}\text { No. of diabetics } \\
\text { (\% for 20-79 yrs) }\end{array}$ & $\begin{array}{l}\text { BMI (kg. } \\
\text { standardized by age) }\end{array}$ & $\begin{array}{l}\text { No. infected / million } \\
\text { population }\end{array}$ & $\begin{array}{l}\text { Mortality } \\
(\%)\end{array}$ \\
\hline Belgium & $3.3 \times 1 \times$ & 6.2 & 4.6 & 26.1 & 6922 & 12.2 \\
\hline France & 3.1 & 6.5 & 4.8 & 25 & 3431 & 13.2 \\
\hline United Kingdom & 2.8 & 2.8 & 3.9 & 27.1 & 4887 & 12.7 \\
\hline Italy & 4.0 & 3.4 & 5 & 25.6 & 4317 & 13.6 \\
\hline Netherlands & 3.5 & 4.7 & 5.4 & 25.6 & 38658 & 0.9 \\
\hline Spain & 4.1 & 3 & 6.9 & 25.9 & 8200 & 7.5 \\
\hline Canada & 2.6 & 2.7 & 7.6 & 26.9 & 3323 & 7.3 \\
\hline Brazil & 2.2 & 2.2 & 10.4 & 26.6 & 17085 & 3.2 \\
\hline Iran & 1.1 & 1.5 & 9.6 & 26.1 & 4356 & 5.8 \\
\hline United States & 2.6 & 2.9 & 10.8 & 28.9 & 17213 & 3.1 \\
\hline China & 1.8 & 4.2 & 9.2 & 23.8 & 65 & 5.2 \\
\hline Germany & 4.2 & 8.3 & 10.4 & 26.6 & 2825 & 4.0 \\
\hline India & 0.8 & 0.7 & 10.4 & 22.8 & 2319 & 1.8 \\
\hline Peru & 1.3 & 1.6 & 6.6 & 26.7 & 18281 & 4.7 \\
\hline Turkey & 1.8 & 2.7 & 11.1 & 27.9 & 3113 & 2.4 \\
\hline Russia & 4.0 & 8.2 & 6.1 & 26.2 & 6692 & 1.7 \\
\hline
\end{tabular}

Data Source: Estimated based on data from World Bank, 2020\&Worldometer, 2020 (accessed on 26 Aug 2020). 
population, lesser are the chances of such country getting affected to a larger extent and vice versa. Similar is the assumption made w.r.t. the number of physicians per unit population.

It may be noted that among the countries severely infected with the dreadful virus, developed countries like Italy, Spain, Germany and Russia had a higher ratio of doctors (over 4 per 1000 people) compared to other developed countries like Belgium (3.3), France (3.1), United Kingdom (2.8), Canada and USA (2.6 each) had lesser number of doctors per thousand populations. More doctors per unit population would mean, the medical attention after infection would be better for patients with such dreadful diseases. Only in the case of Russia and Germany, the mortality rate is lower $(<5 \%)$, partly attributable to a higher proportion of doctors in these two countries. As far as catching the infection is concerned, it is always attributed to the general health condition and also the immunity levels. Body Mass Index (BMI) to a large extent would indicate the same. The correlation coefficient between the variables (BMI and no. infected / million population) was positive $(0.41)$ but not significant even at the $10 \%$ level. Correlation coefficient between Recovery rate \& no. of hospital beds is significant at $5 \%$; between no. of physicians \& recovery rate is not significant.

Table 2: Recovery Rates of COVID-19 Patients

\begin{tabular}{|c|c|c|c|c|}
\hline $\begin{array}{l}\text { Sl. } \\
\text { No. }\end{array}$ & Country & $\begin{array}{l}\text { No. of cases/ } \\
\text { million } \\
\text { population }\end{array}$ & $\begin{array}{l}\text { Mortality } \\
\text { rate (per } \\
\text { million) }\end{array}$ & $\begin{array}{l}\text { Recovery } \\
\text { rate, \% }\end{array}$ \\
\hline 1 & USA & 17978 & 551 & 55 \\
\hline 2 & Brazil & 17267 & 548 & 78 \\
\hline 3 & India & 2341 & 43 & 76 \\
\hline 4 & $\begin{array}{l}\text { Russian } \\
\text { Federation }\end{array}$ & 6620 & 114 & 81 \\
\hline 5 & $\begin{array}{l}\text { South } \\
\text { Africa }\end{array}$ & 10317 & 224 & 85 \\
\hline 6 & Peru & 18383 & 847 & 68 \\
\hline 7 & Mexico & 4403 & 476 & 69 \\
\hline 8 & Colombia & 11030 & 351 & 70 \\
\hline 9 & Chile & 20949 & 572 & 93 \\
\hline 10 & Iran & 4318 & 248 & 86 \\
\hline
\end{tabular}

\section{Coverage of COVID Tests across Major Infected Countries}

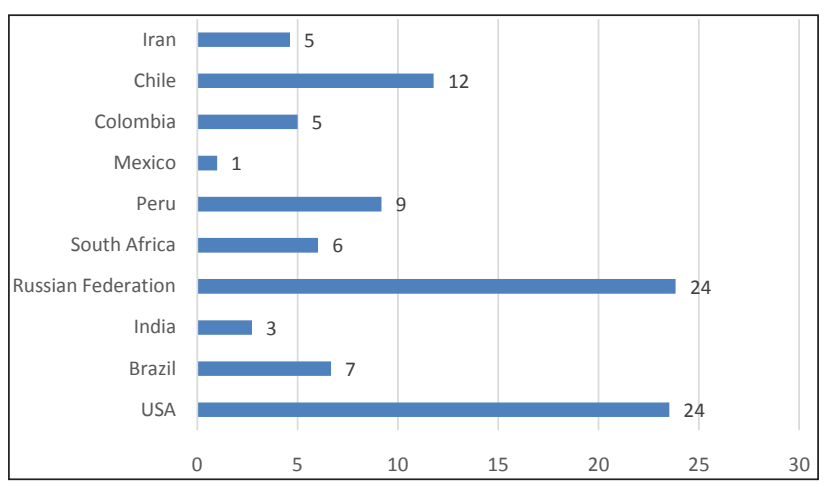

Fig. 4: Percentage population covered for Diagnosis of COVID 19

Data source: Worldometers, 2020 (accessed on 26 Aug 2020.

\section{Economic Status and Impact of COVID-19}

The economic status of countries can be defined as well being of the populations across these countries which gets reflected in their per capita income, level of urbanization, \% of organized labour, unemployment rate, reduced poverty, the growth rate of the economy, foreign exchange reserves, trade balance and economic complexity index. Urbanization of the countries seems to have a positive and significant influence on the COVID-19 incidence (Table 3). It may be noted that higher the population share living in urban areas, higher is the incidence of COVID-19, as evidenced by the figures and the correlation coefficient value.

Table 3: Urbanization and Infection Ratios across Countries

\begin{tabular}{lll}
\hline Countries & $\begin{array}{l}\text { \% Urban } \\
\text { Population }\end{array}$ & $\begin{array}{l}\text { Infected population/ } \\
\text { million }\end{array}$ \\
\hline Singapore & 100 & 3989 \\
Belgium & 98 & 4538 \\
Netherlands & 91 & 2473 \\
Sweden & 87 & 2567 \\
Brazil & 86 & 734 \\
Saudi Arabia & 84 & 1067 \\
UK & 83 & 3171 \\
USA & 82 & 4070 \\
S. Korea & 82 & 212 \\
Canada & 81 & 1794 \\
Spain & 80 & 5620 \\
France & 80 & 2706 \\
Mexico & 80 & 260 \\
Peru & 78 & 1972 \\
Germany & 77 & 2045
\end{tabular}




$\begin{array}{lll}\text { Turkey } & 75 & 1626 \\ \text { Switzerland } & 74 & 3495 \\ \text { Russia } & 74 & 1437 \\ \text { Iran } & 74 & 1265 \\ \text { Italy } & 70 & 3610 \\ \text { Portugal } & 65 & 2688 \\ \text { China } & 58 & 58 \\ \text { Pakistan } & 36 & 133 \\ \text { India } & 34 & 46 \\ \text { World } & 55 & 528\end{array}$

Note: Correlation coefficient: $0.51 \mathcal{E}$ it is significant at 0.05 level.

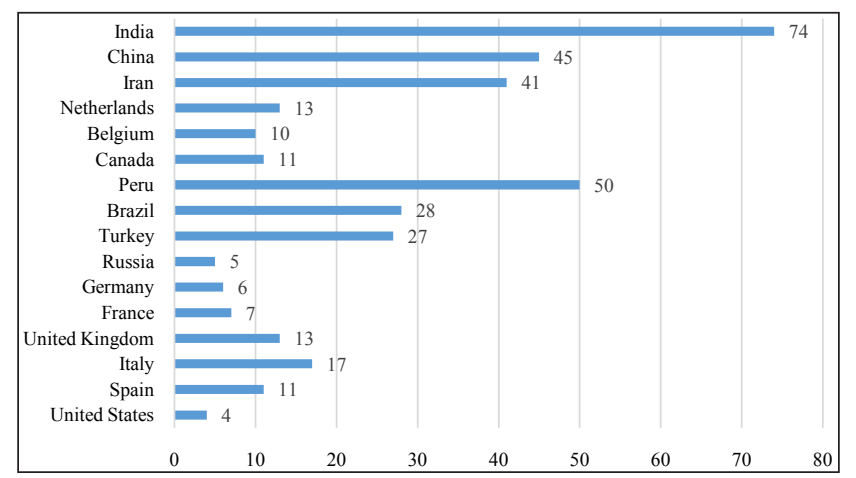

Fig. 5: Unorganized (vulnerable) employment share, \%

It may be noted that unorganized employment is prevalent in the range of $4-74 \%$ (Fig. 5). Lower rates of informal employment exist in countries like the USA, Russia, Germany and France (4-7\%). Generally, unorganized employment, which is mostly in the informal sector, means insecure livelihoods. Several countries affected by the pandemic have higher levels of such employment like India and Peru with 74 and $50 \%$, which means during and post COVID-19 incidence, the recovery and stability of such populations is that much difficult, as they do not get assured income and social security benefits. This was emphasized by Fernandes (2020). Therefore, this aspect must be seriously given a thought by the respective governments.

Coupled with the unorganized labour status, the actual unemployment level also causes problems for the COVID-19 affected nations. Higher employment was seen in countries like Spain, Turkey, Brazil and Iran, which is above $10 \%$. Generally, the unemployment rate (\% of eligible labour to unemployed) has come down in the last decade (2010-2019), except in the case of Turkey, Italy and Brazil.

Another important economic indicator that influences the extent and longevity of the pandemic impact would be the poverty ratio of the countries. India's poverty rate was the highest at $19 \%$ during 2018, compared to single-digit and lower poverty rates in the range of 0 (France) $-3.7 \%$ (Brazil) during 2018 (Fig. 7). Generally, the poverty rate has come down in the period 2010 to 2018. This implies that countries with higher poverty rates have to be doubly careful in managing the pandemic in order not to have further complications during and after the pandemic.

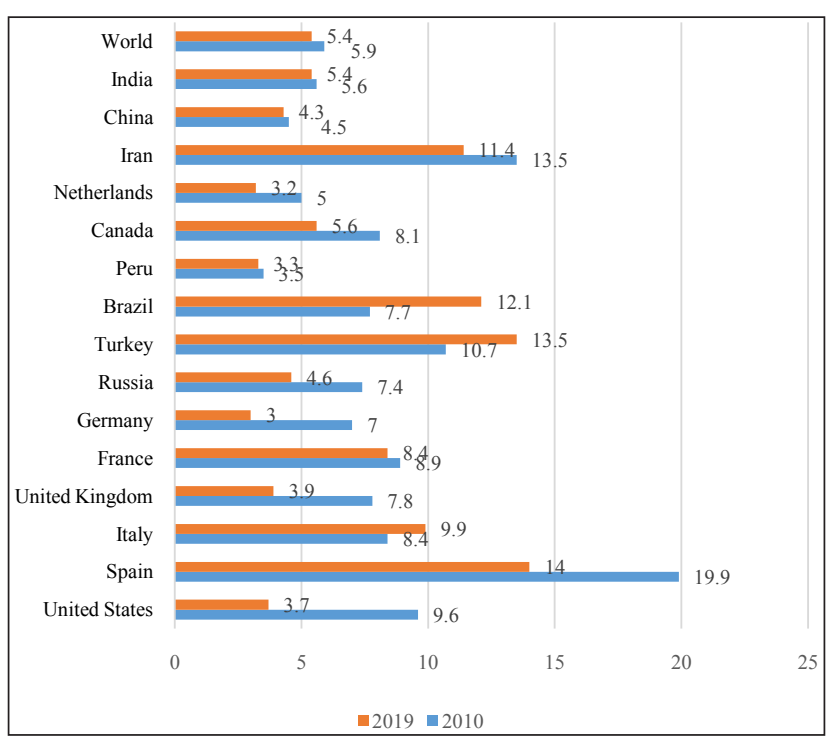

Fig. 6: Unemployment rate (\% of total labour force)

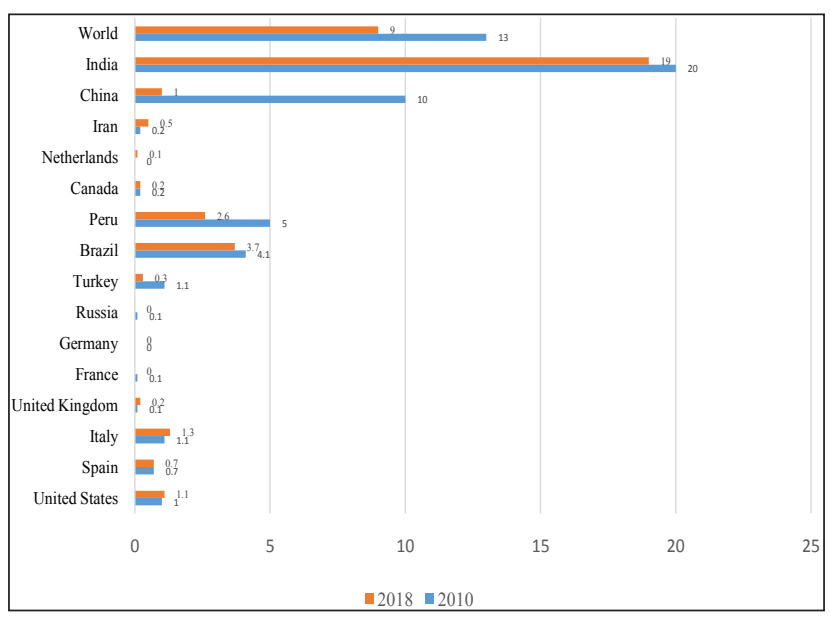

Fig. 7: Poverty Gap in COVID-19 Infected Countries (@ \$3.2/ day at 2011 constant prices)

The growth rate of an economy indicates the state of the country, whether it can absorb the shocks caused due to pandemic or any other socio-politicoeconomic emergency. Therefore, a comparison of countries' growth rate was done (Fig. 8). Among the affected countries, China and India alone had 
a better growth rate (6 and $5 \%$ ), while the rest of the nations had a lesser growth rate (0.1 to $3.2 \%)$.

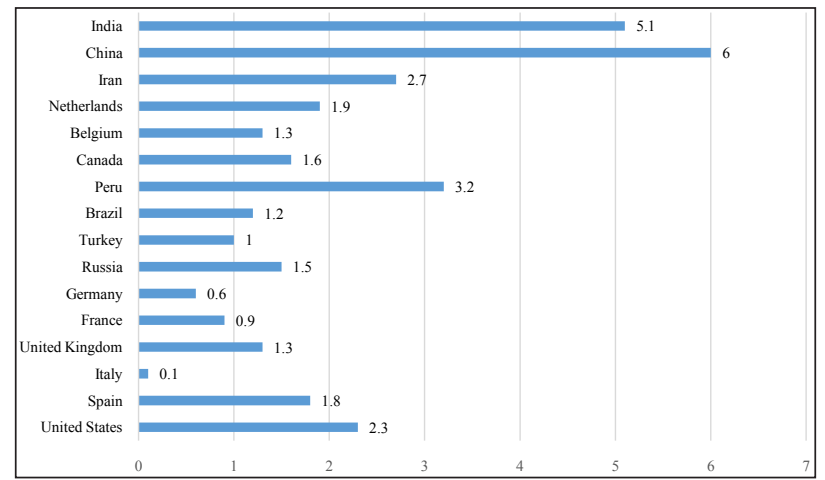

Fig. 8: Growth rate of COVID-19 Infected Economies, \% YoY (FY 2019)

Yet another but important economic indicator of a country is the foreign exchange reserves. This will denote not only the trade balance status but also the general financial health of any country in the eyes of other countries (Fig. 9). The per capita foreign exchange reserves were the highest in Russia during 2019 with the US \$ 3213 and it was the lowest in Iran (the US \$ 93).

The Economic Complexity Index (ECI) and the Product Complexity Index (PCI) are, respectively, measures of the relative knowledge intensity of an economy or a product. ECI measures the knowledge intensity of an economy by considering the knowledge intensity of the products it exports. It may be noted that China, Germany, Russia, Italy, Brazil and Canada are better in terms of their trade balance (positive).

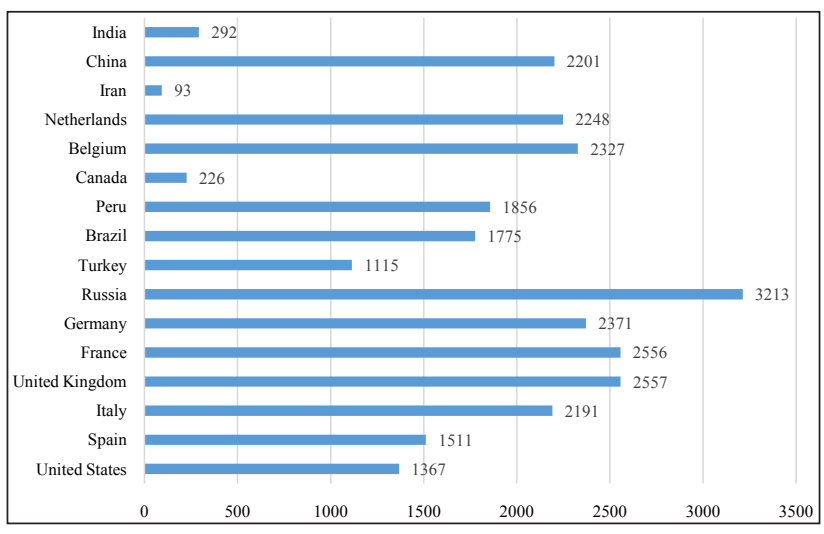

Fig. 9: Foreign exchange reserves per capita (US \$)

But in terms of ECI, Germany is on top with a value of 2.08 followed by the USA, that signifies their knowledge dominance and innovation in products (Table 4). Similarly, these two countries along with the Netherlands are the leaders in terms of their per capita incomes.

\section{Impact on General Economy and Trade}

The COVID 19 pandemic is impacting the global economy severely (Chakravarthyand Maity, 2020). Trade at the global level will be impacted badly

Table 4: Exports Vs Imports and Per Capita Income of Major COVID affected countries during the year 2017

\begin{tabular}{llllll}
\hline Country & $\begin{array}{l}\text { Exports (Billion } \\
\text { \$) }\end{array}$ & $\begin{array}{l}\text { Imports (billion } \\
\mathbf{\$} \text { ) }\end{array}$ & $\begin{array}{l}\text { Trade Balance } \\
\text { (Billion \$) }\end{array}$ & $\begin{array}{l}\text { Economic Complexity } \\
\text { index }\end{array}$ & $\begin{array}{l}\text { GDP per capita } \\
\text { (\$) }\end{array}$ \\
\hline United States & 1250 & 2160 & -910 & 1.76 & 59500 \\
Spain & 460 & 433 & 27 & 0.85 & 30523 \\
Italy & 482 & 441 & 41 & 1.12 & 39400 \\
United Kingdom & 395 & 617 & -222 & 1.53 & 43300 \\
France & 516 & 595 & -79 & 1.39 & 42900 \\
Germany & 1330 & 1080 & 250 & 2.08 & 50600 \\
Russia & 341 & 221 & 120 & 0.85 & 25500 \\
Turkey & 166 & 214 & -48 & 0.18 & 26500 \\
Brazil & 219 & 140 & 79 & 0.61 & 15500 \\
Peru & 44.8 & 38 & 6.8 & -0.6 & 13400 \\
Canada & 377 & 326 & 51 & 1.06 & 46700 \\
Netherlands & 461 & 485 & -24 & 1.3 & 52500 \\
Iran & 53.7 & 49.9 & 3.8 & -0.16 & 20800 \\
China & 2410 & 1540 & 870 & 0.69 & 16800 \\
India & 292 & 417 & -125 & 0.36 & 7060 \\
\hline
\end{tabular}

Source: https://oec.world/en/rankings/country/eci/ 
and is likely to lose between 13-32\% during 2020 (WTO, 2020). All countries will be affected badly with declines in their trade volumes during 2020. UNCTAD (2020) has analyzed the quick impacts and indicated the following on the general status of the economies to be affected:

- There will be contracting of all economies due to the sudden drop in economic activities

- Adverse impacts will be seen on financial markets, consumption, the confidence of investors, trade and commodity prices etc

- The situation will be much worse than the 2008 financial crisis, where the currency prices will be dropping twice or thrice compared to 2008 falls

- Commodity prices likely to fall up to $60 \%$ of normal

- Food prices may slump by $10-20 \%$

\section{Impact on Agriculture}

An ILO report (ILO, 2020) indicates that as agriculture provides livelihoods for more than one billion people worldwide, despite the employment provided by the sector accounts for only $26.8 \%$ of the total employment at the global level. For the low-income countries, agriculture is still the mainstay with over $60 \%$ employment provider and significant share in GDP of such countries. Those engaged in agriculture also face extreme poverty and it is often proved that growth in agriculture directly leads to reduced poverty (Janvry and Sadoulet, 2010). The measures to tackle the spread of COVID like lockdown and movement restrictions naturally hamper the lives of farmers, farm labour as a flow of inputs and outputs and movement of labour and machinery are badly affected (Kumar and Kumar, 2020). As a result of these things come to a standstill. The badly affected commodities will be the perishables which rot on the farm, on route to market, spoilage due to breaking of cold chains and longer time in transit and many other ways. Some specific impacts of the pandemic on Indian agriculture as reported by FAO are as follows:

- Wheat harvests slowed down.

- Maize prices slumped due to low demand.

- Fruits and vegetable supplies were just onefourth of normal in Azadpur Mandi, the largest market of Asia.
- Agriculture labour of India, who are the lifeline of agricultural operations are empty-handed.

\section{CONCLUSION}

Policy responses of various kinds are coming forth by the respective governments and also by the World Bank and the FAO. Some of those significant moves are as follows:

- Canada has increased agricultural credit by CAD 5 billion and another CAD 100 million for food security across the country. Further workers who are unable to work due to medical reasons can avail $55 \%$ of their earnings as employment benefit limited to CAD 573 a week.

- China has extended RMB (Chinese Yuan) 500 billion expansion of re-lending at lower interest to MSMEs. For agricultural workers temporary living allowance of RMB 300 provided.

- Egypt has extended the moratorium on tax for agricultural holdings by two years.

- Fiji has supported short term crops by distributing seed and inputs and has also given relief of \$150 for workers of the informal sector.

- Germany has extended the number of days of working for agricultural labour by $50 \%$ more days and has exempted them from paying social security contributions.

- India has announced a slew of packages such as free food grains for the ration cardholders in addition to the regularly paid ration, interest subvention and additional credit tranche for MSMEs for the three months, direct cash transfer@ ₹ 500 per family for Jan Dhan account holders, plans for building residential complexes for migrant labour in urban areas in PPP mode etc.

World consortium of civil society organizations has urged for maintaining food supply chains across the globe through open trade, investments in resilient food systems and scaling up support for highly vulnerable populations. All these and many more support measures not only to satiate the hunger but also to maintain the dignity and honour of all classes, especially the severely affected migrant labourers in urban areas are needed especially in countries like India to tackle the extraordinary situation. To manage the situation arising out of 
COVID -19 pandemic, the developing countries especially need to focus on unlearning the following:

- The infrastructure available for health and the quantity and quality of medical and paramedical manpower.

- A storehouse of economic development plans in times of emergencies and their automatic implementation, instead of searching or debating on them when emergencies occur.

- Instead of making poor and the hapless to suffer in such emergencies, measures to help and take care of them first need to be taken up.

- The production paralysis created due to lockdown shouldn't have happened, which could have been exempted straight away.

- The contingency measure plans for agriculture are available looking at the climate aberrations, but contingency plans for medical/pandemic situations also need to be incorporated into them.

\section{REFERENCES}

Bahadur, P.P., Poudel, M.R., Gautam, A., Phuyal, S., Tiwari, C.K., Bashyal, N. and Bashyal, S. 2020. COVID-19 and its Global Impact on Food and Agriculture. J. Biol. Today's World, 9(5): 221.

Fernandes, Nuno, Economic Effects of Coronavirus Outbreak (COVID-19) on the World Economy (2020). SSRN: https:// ssrn.com/abstract=3557504 or http://dx.doi.org/10.2139/ ssrn.3557504

https://www.britannica.com/science/virus[Last accessed on 2020 April 30] https://www.virology.ws/2004/06/09/are-viruses-living/ [Last accessed on 2020 April 30]

https://www.who.int/news-room/q-a-detail/q-acoronaviruses [Last accessed on 2020 April 29]

https://www.worldometers.info/coronavirus/countrieswhere-coronavirus-has-spread/[ Last accessed on 2020 August 24]

ILO. 2020. ILO Sectoral Brief. International Labour Organization. 17 April 2020, pp. 7.

Indranil, C. and Maity, P. 2020. COVID-19 outbreak: Migration, effects on society, global environment and prevention. Sci. Total Environ., 728: 138882.

Janvry Alain de and Sadoulet, E. 2010. Agricultural Growth and Poverty Reduction: Additional Evidence. World Bank Res Observer, 25(1): 1- 20.

Kumar, N. and Kumar, A. 2020. Farmers may not be infected but are certainly affected. https://www.livemint.com/ opinion/online-views/farmers-may-not-be-infectedbut-are-certainly-affected-11585597865710.html. [Last Accessed 2020 May 4].

Ozili, Peterson, K. and Arun, Thankom, 2020. Spillover of COVID-19: Impact on the Global Economy. SSRN: https:// ssrn.com/abstract=3562570 or http://dx.doi.org/10.2139/ ssrn.3562570.

UNCTAD. 2020. The Covid-19 Shock to Developing Countries: Towards a "whatever it takes" programme for the two-thirds of the world's population being left behind. https://unctad.org/en/PublicationsLibrary/ gds_tdr2019_covid2_en.pdf. Last [Accessed 2020 May 8.]

World Bank. 2020. https://data.worldbank.org/indicator/ SH.MED.PHYS.ZS.

WTO. 2020. Trade set to plunge as COVID-19 pandemic upends global economy. https://www.wto.org/english/ news_e/pres20_e/pr855_e.htm. [Last Accessed 2020 May 2]. 